\title{
A STUDY ON THE CORRELATIVE RELATIONSHIP BETWEEN PNEUMATIZATION OF THE TEMPORAL BONE AND THE BONE MARROW SPACE IN THE RIPE FETUSES
}

\author{
By

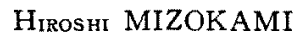 \\ From the Department of Oto-Rhino-Laryngology, School of Medicine, \\ Nagasaki University (Director: Prof. T. Goto)
}

In the mucous membrane of the middle-ear of the neonates and the fetuses in the last stage, we found an inflammatory change, so called an otitis neonatrum.

This is a usual process with pnenmafization of.

The author produced sectional specimens of the temporal bones, sternums, humerus and femurs of the ripe fetuses, and photographed these microscopical specimen, then, measured the bone marrow spaces of the microphotographs by planimeter.
On the other hand, the auther carried out a research for the microscopical state in the round of the middle-ear spaces. The results were as follow: the wide bone marrow spaces in the temporal bones had the wide bone-marrow spaces in the other bones, and these were remarkable cellular infiltration in the mucous membrane of the middle-ear.

Pneumatization widely depends upon the constitution of indivisual.

\section{胎児の側頭蜂窠の発育之邲幹骨骨䯣腔との \\ 関連性に関する研究}

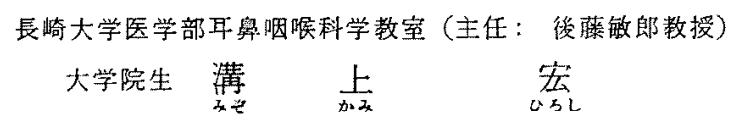

\section{目次}

I 緒言

】研究方法

1. 研觉材料

2. 標本の作幣法

3. 骨髄腔の広さの测定法

4. 組織学的钼察

III 研觉成蹋

1. 骨䯣腔の広さの測定

2. 中耳腔周辺の組織学的観察について

N 總括及び考按

$\mathrm{V}$ 結 言

VI参考安献

\section{I 腥 言}

新生児の中耳腔内に炎症様所見が極めて多数の例飞お いて認められることは，古くから注日されていたことで あつたが，1918 年に，Wittmaack がこの资症様变化 を所謂 latente Säuglingsotitis と呼んで蜂策抑制の原 因とみなし，彼の Pneumatisationslehre の根拠とし た.

しかるに, 近年, 後藤教授 ${ }^{239}$ 《蜂䆵再生現象の発見 からその組織学的研究を進めるうちに，この Pneumatisationsproblem の根拠をなす latente Otitis といわ れる炎症様所見は，Pneumatisationshemmung の原因 とみなす促来の学説に疑問を抱き，他面また，この現象 な病的とみなすことの不合理なことより，この現象の再 


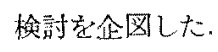

杨野4)をはじめ，当散室の合気化問題に関する一璉の 研究の゙によつて，この新生兒の中耳腔粘膜に認められ

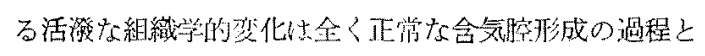
して，骨吸收に刘する度応であることを明らかにした。

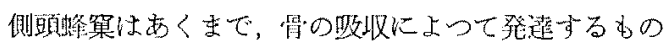

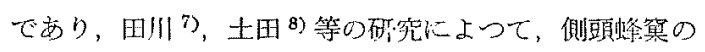
形成には，ての骨週腔が大きな役制をはたしていること が知られた。

しかるに，側頭嗮染には，著しい個体善が存在してい る.この強い個体差の成因に间しては，既飞Wittmaack 以来，その発育抑制状態がとりあげられて，感ん に諭議され，成因について，炎症説と遗伝説の二つの説

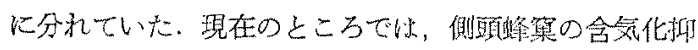
制の成因としては，遗伝体質的なものとする説がつよ く，当教室の業績 1011112) むこの説省立証している.

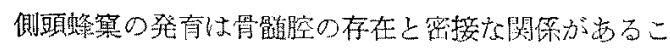
とから，体貿的なものであることが考光ら机るが，むし

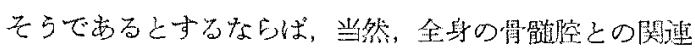
性が考点られる。果して，側頭骨の骨䯙腔の発育の良否

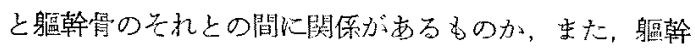

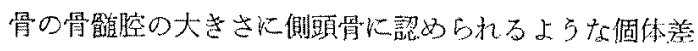
があるものかどらか，この間題の吥究のために，著者は

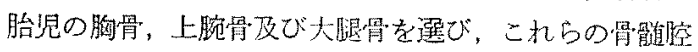
の広さと側頭骨のそれとを比較した。

また，中耳腔内には， latente Otitis 上呼ばれた異物 炎が訛められるとされているが，これらの炎症様所見に ついて観察するととるに，その時期に相当する軀幹骨の 骨餚䅝の状態定観察した。

\section{II 研究方法}

1. 研究材料

この研究月的飞, 観察の材料上して泟, 本学解剖学第 一教室上り得られた人胎睍 25 例党用いた，胎是を用い

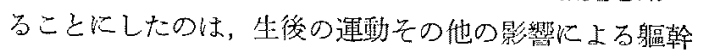
骨の变化を除くためと，骨組織の全体的な比較を容易に

表 1

\begin{tabular}{|c|c|c|c|c|c|c|c|c|}
\hline 月令 & 10 & m & 月 & 9力月 & 力月 & $7 \%$ & 月 & 6 \\
\hline 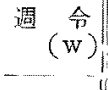 & 40 & 38 & 37 & 36 & 32 & 28 & 25 & 24 \\
\hline 数 (体) & 4 & 3 & 4 & 4 & 4 & 3 & 1 & 2 \\
\hline
\end{tabular}

少るためである。

矿究材料の週令, 月令及び数は表 1 の通りである.

以上の胎胃の側頭骨，胸骨，上腕骨及び大腿骨を摘出 し，連続切片標本を作製した。

2. 標本の作梨法

摘出材料は一是夜水洗し，約了日閒10\%フォルマリン 液に浸漬後，漸次上昇及び下降アルコール列を通して脱 脂脱水し， $2 \%$ 硝酸液で脱灰した，次いで，水洗し，5 $\%$ 悡水芒硝で中和し，再度，アルコール列を上年，下降 させて，次に，2\%，4\%，6\%，8\%の Celloidin 液に それぞれ約ふ〜4週間浸して，13\% Celloidin で包埋し t.

かくして得た包埋標本より，側頭骨は矢状面に平行 に，胸骨は平湎に平行に，上腕骨及び大腿骨恃長朝平

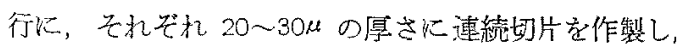
へマトキシリンーエオジン染色を行つて，組織標本を得 t心.

\section{3. 骨髄腔の広さの測定法}

骨骮腔の人いさを量的に比較することは極めて因難で 方るが，実施可能应籍囲の方法として，次の如き方法を 選んだ。

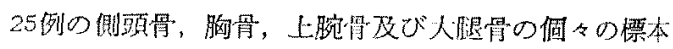
のらち、注ぼ同一部位を5 力所選んで 40 倍の顕微鏡写 真を撮り。これをA 4 版の印画継に等きつけて，写真上 の骨骮腔の面積を補整プラニメーターで測定し，その5 カ所の平均值を写真上の全骨䯣面積に対する百分率で表 わすう法をとつた

\section{4. 組織学的钼察}

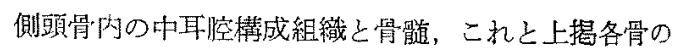

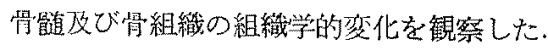

1. 骨䯙膑の広さの測定

\section{III 研究成瞔}

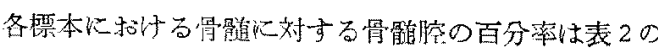
A閩に示方通りである。

この25例の測定に括いての平约值は，側頭䯚では $62.2 \%$ ，胸骨では $71.6 \%$ ，上腕骨で就 $62.6 \%$ ，大腿骨 では66.0\%であつた。

著孝仙側頭骨の骨噵腔の大小と他の骨のそ机との間の 関係をみるために，25例の側頭骨，胸骨，上腕骨及び大

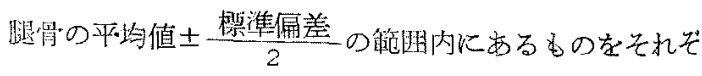
れの中央値（骬䯣㓐の広さの平均的なるの）とみなし， これより大きいるのを「大、，小さいるの机「とし 
表 2 骨髏空の匝さ

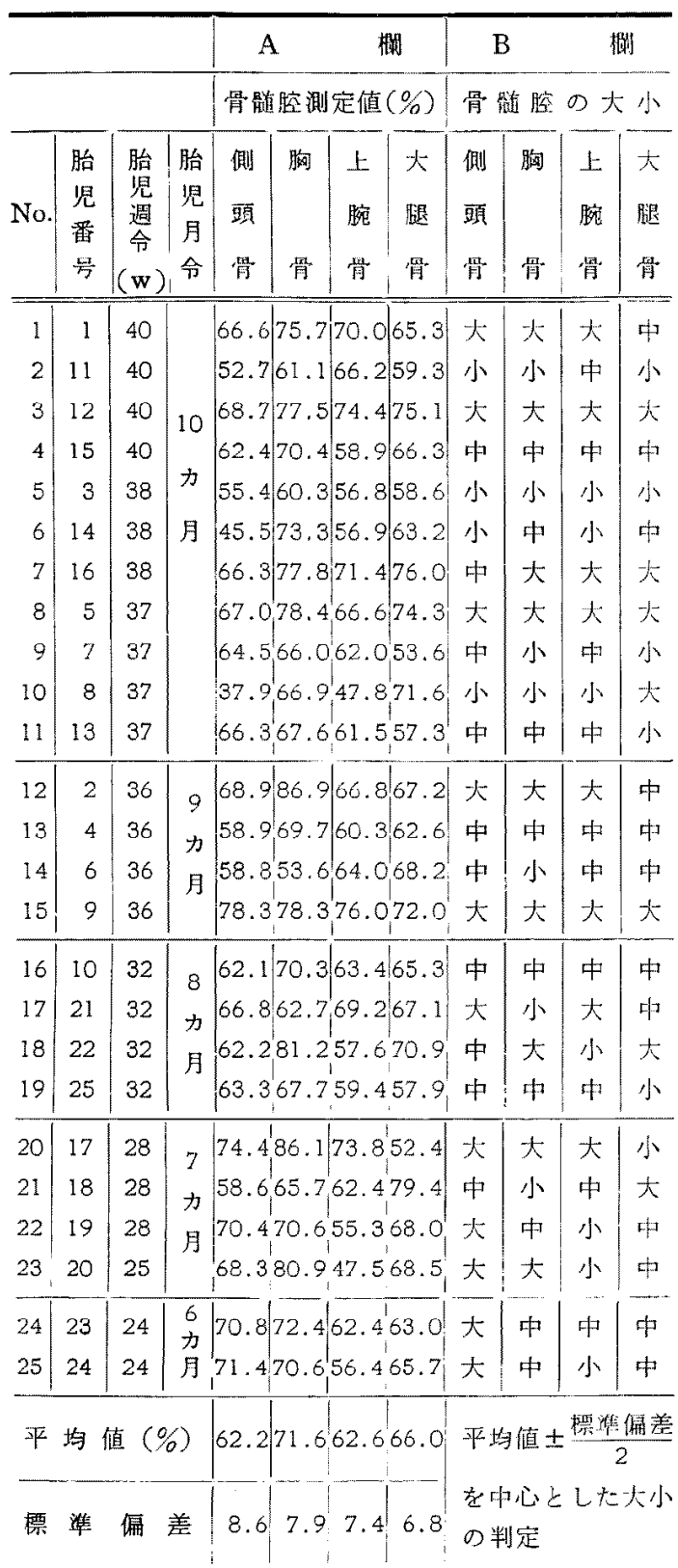

て大小を判定した，その結果は表 2 のB檘に示卞通りで ある。

測定值において，骨䯙腔の広さが平均的に，側頭骨く 上腕骨く大眼骨く胸骨の順になつていることは，写真5，

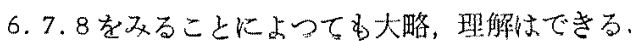

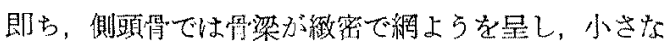
骨䯣腔が集合しあつた形をとつているので，䬽腔は総体 的に恬小さくなつている。 しかし，奻若な6〜7カ月の 胎胃の側頚骨では，骨梁ぶ短く，胸骨の骨骮像に似た形 をしているので，その測定值も胸骨の平均值に近い，

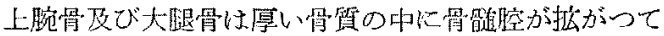
いて，罗梁は部位儿上つて形が䔬ならているが，側頭骨 の上らに效叉したものが少ないので，総体的には大きい 倠ぶ得ら机たのであるう。

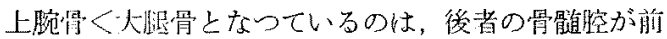
者のそれよりも縱横共に大きいために，著者の测定方法 によつては，大きな值となつたのであろう。

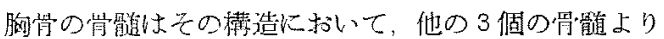
も幼若な形を是し，成熟胎胃でも，樕骨性の骨化を行つ ていて，䯈梁は短く，ま大，交叉したものが少いので，

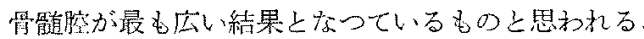

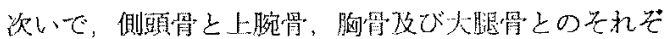
れの関係吉检討すると，

i）側頭骨と胸骨との関係 (図 1-A及び表 3-A)

図1ーAで示寺ららな関係がある。

いま，8力月以降のものと，6〜7力月のものとを分け て観察すると，6〜7 力月のものには殆んど相関関係が 謥められないことが分る。こ犼在だ，それぞれの骨，

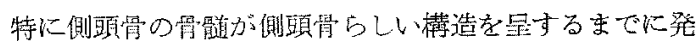
造分化してい㳊いということに 由来していると思わ机

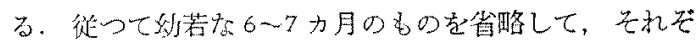
れを比較する上，表3-Aに示主上5飞，19 例中 13 例飞

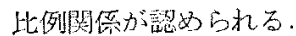

ii）側頭骨と上腕骨との関係（図 1-B 及び表 3-B）

同棒な力法によつて，㑡頭骨と上腕骨との間には，8 力月以降の例で好，19 例中 16 例飞比例闗係が認められ る。

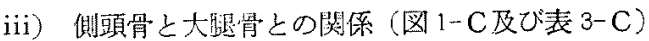

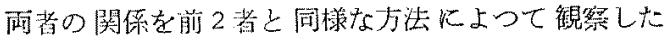
が，側頭骨と大腿骨との間では，19例中10 例飞比例関 保が認められた。

こ机は大眼的が他の骨に比べて極好て大きく，著者の 行つた測定部位はその狭い釷围のものであつたことをも

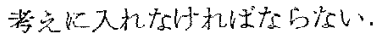

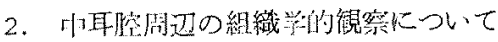

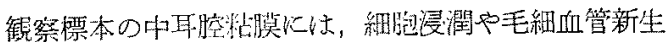

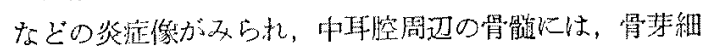
胞及び破骨紐配が認められることなどは，正常含気腔形 


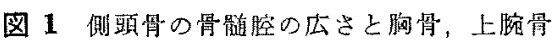
及び大腿骨の骨针腔の広さとの関係

○印は 8 力口以降の胎児

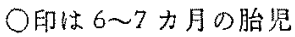
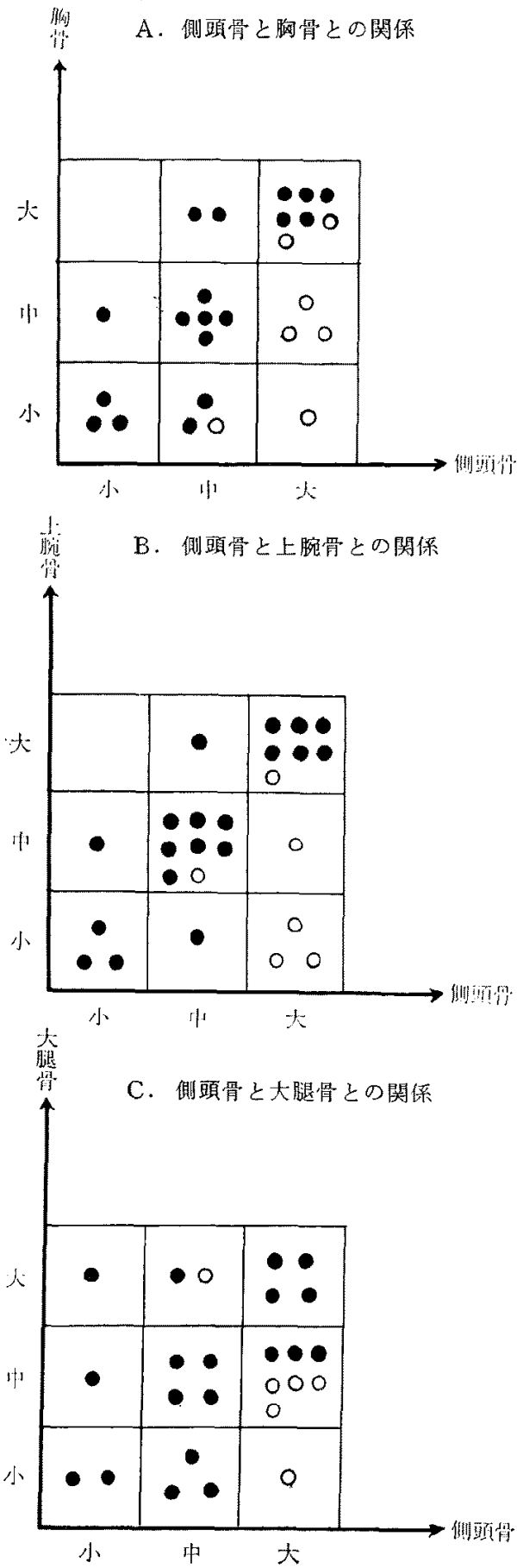

表 38 力月以降の胎児の僛頭骨の骨髄腔と胸 骨，上腕骨及び大腿骨の骨路腔の 広さに括讨関係

A 、側頭骨之胸骨の関係

\begin{tabular}{|c|c|c|c|c|c|}
\hline \multicolumn{2}{|c|}{ 仳 } & 碩 & \multicolumn{2}{|c|}{ 骨 } & 橭 \\
\hline \multirow{2}{*}{ 胸 } & & 小 & 中 & 大 & \\
\hline & 小 & 3 & 2 & 1 & 6 \\
\hline \multirow{2}{*}{ 筒 } & 中 & 1 & 5 & & 6 \\
\hline & 大 & & 2 & 5 & 7 \\
\hline 計 & & 4 & 9 & 6 & 19 \\
\hline
\end{tabular}

B. 僛颔骨と上腕骨の関係

\begin{tabular}{|c|c|c|c|c|c|}
\hline \multicolumn{2}{|c|}{ 側 } & 頭 & \multicolumn{2}{|c|}{ 牊 } & 部 \\
\hline \multirow[t]{2}{*}{ 上 } & & 小 & 中 & 太 & 喰| \\
\hline & 小 & 3 & 1 & & 4 \\
\hline 腕 & 中 & 1 & 7 & & 8 \\
\hline 骨 & 大 & & 1 & 6 & 7 \\
\hline 計 & & 4 & 9 & 6 & 19 \\
\hline
\end{tabular}

C．側頭骨と大腿骨の関係

\begin{tabular}{|c|c|c|c|c|c|}
\hline \multicolumn{2}{|c|}{ 側 } & 頡 & \multicolumn{2}{|c|}{ 骨 } & 計 \\
\hline 大 & & 小 & 中 & 大 & \\
\hline & 小 & 2 & 3 & & 5 \\
\hline & 中 & 1 & 4 & 3 & 8 \\
\hline & 大 & 1 & 1 & 4 & 6 \\
\hline 計 & & 4 & 8 & 7 & 19 \\
\hline
\end{tabular}


成機序の一過程であり，既火 latente Säuglingsotitis として知られているが，胎令を追って，その炎症様現象 を観察することとした。

i）6力月の胎児の中耳（2 例)

側頭骨全体が軟弱な感じで，単純な洞をなした中耳腔 には，所々に胎生組織としての網状組織が認められ，一 例では中耳腔がほぼ完全な洞腔をなつていたが，他の一 例ではいまだ中耳腔が胎生組織でみたされていて，完全 な洞腔となつていない。

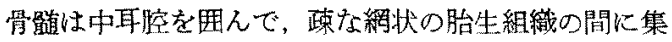

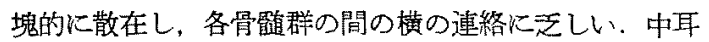
腔側と外皮質部側に存在する骨䯈の中には線維性の厚い 組織が侵入しているが，中央部は rotes Mark 上り成 り，血球細胞集簇の中に，大きな胞状の骨細胞上り成る 骨梁が浮いている感じである。

骨㴤の面炕骨芽細胞が一列に並び，その反䁌面には 破骨細胞も認められる。

中耳腔粘膜の表㬝には，一列の原形質の狭い立力形 の細胞が並び，深層は網状の突起を持つた極めて眯な myxom 状の組織より成つている。これらの組織の層の 厚さは部位によつて甚だしく異なつている。

骨壁に接する部位の結合織は線維性であって骨梁の表 層には多くは骨芽細胞が一列に並えでいる。

毛細血管は粘膜の表層近くに多く，深部で恃少ない。

ii) 7 力月の胎滉の中耳 (3 例)

胎週 25 週の例では，6力月の例と大羓がないが，28 週の例では，中耳腔が殆しど完全な洞腔を形成してい て，粘膜は場所によつて，その厚さが異なつているが， 一般に薄くなり，粘膜の表層には今方形の細胞の存在が 密で，骨壁に近い部分では線維性の組織の增殖が認めら れる。

場所以よつてはまた。，厚い胎生様組織方疜在し，毛練 血管の增殖も6力月の例よりも粘膜下の深部に著明にな つている.

骨䯣は6力月の例よりも大きくなつて，特に，rotes Mark の部分が厸い。

iii) 8 力月の胎昆の中耳 ( 3 例)

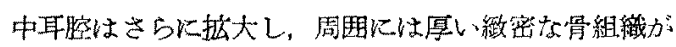
目立ち，中耳腔粘膜には所々に胎生組織様の結合織が認 められているが，全体的には，その厚さ之量を減し，線 稚性なものと变つている，

立方型の上皮細胞は 7 カ月のものと大差がないが，骨 这では, 中耳腔周辺の骨梁が著しく厚くなり、線維性の
Mark の部分を䋧て, rotes Mark に続いている.

骨梁は互に連絡し，網状を是し，骨芽細胞及び破骨細 胞の出現が多い.

iv）9 月月の胎罗の中耳 (4 例)

観察例は㑮か 4 例であるが，眖体差が特著明とな り，1例では，所謂 Säuglingsotitis といわれる練胞浸 潤の極好て藷しい、例が認好机た。

乙加上，全般的飞质る上，中耳腔周边の骨梁が，8力 月の例に此らべて，機延びた感じを与克ている。

骨深は薄くなり，整然とした網様の形を呈し，粘膜下 の紏胞浸潤の著明な例では，骨髄腔内に上皮細胞で被わ れた小胞が随所儿認好られる。

かかる例比対して，骨梁が厚く，骨䯣柼の狭い例で

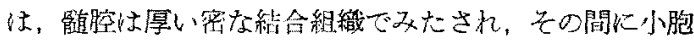
の存在は㒛められず，骨深面以破骨細胞は少なく，粘 膜下にも細胞浸䦌仙少ない。

毛細血管は幼若な例に比らべて，㳭部でその大きを 增している。

v) 10 力月の胎児の中耳（11 例)

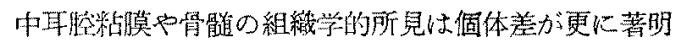
となり，所謂炎症様所見に個体差が著しい。

炎症様所見の堷明な例では，中耳腔内约上皮細胞様の 大円形綝胞群の遊出が著时で，粘膜下には表層，樑層々

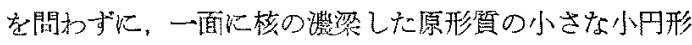
紐胞が浸潤している。

洞腔の小さな会気化不良の例では，甲カ月の不良の例 に認められた所見と大差がない，

一般に中耳腔佂面した部分の骨䯣は結合織比富み，骨 梁緑には破骨細胞が散在し，骨の吸収像が著明である。

以上を要䄪すると， 6 力月以降の胎見の中耳腔粘膜下 に法，小円形細胞の浸閵が認められるが，胎令が進むに つれて綀胞浸潤の程度は著しくなる。しかし，9力月頃 から，この細胞浸潤㑑体差が著明となつてくる。

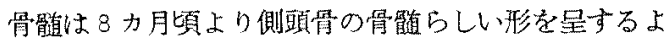
らになり，䯣腔には中耳腔側と外皮質側上り線維性の 細織が侵入してきて，胎令が進しとともに，fibröses Mark の箱䀧が脑大寸るが，中央部には10カ月の例に 颃いても，な括 rotes Mark が存在している。

粘膜下組織の細胞浸閏の著明な例では，fibröses Markに向つて上皮下維織が侵入している像が認好られる。 また， rotes Mark の部分に㧊いても上皮下結合織が侵 入している像が諗められ，骨髅腔の線維化が行われてい， る如くに見受けられる。 


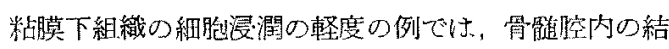

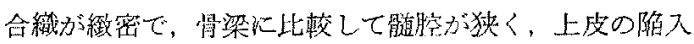
部も少ない。

以上のよ5に，胎生未期の中耳腔の構成組織には，組 継学的に活潑な動きがあることがわかるが，これを週命 に従つて，数値的に表らわすことは不可能である。

者者は中耳腔粘獏でば細胞浸潤と毛細血管，胃䯣では

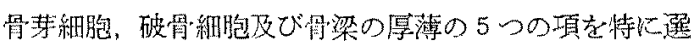
んで段階に分けて，その程度を判定した。

細胞浸潤及び毛細血管新生の著明な例を「H」，藷明 でない例を「十」，その中間の例学「H」とし，骨莱細 胞及び破骨細胞では厨めて多いものを「H」，少ない例

表 4 中耳腔粘膜の組維像

\begin{tabular}{|c|c|c|c|c|c|c|c|c|}
\hline No. & $\begin{array}{l}\text { 胎 } \\
\text { 児 } \\
\text { 番 } \\
\text { 号 }\end{array}$ & $\begin{array}{c}\text { 胎 } \\
\text { 思 } \\
\text { 週 } \\
\text { 命 } \\
(\mathrm{w}) \\
\end{array}$ & $\begin{array}{c}\text { 胎 } \\
\text { 兒 } \\
\text { 月 } \\
\text { 令 }\end{array}$ & $\begin{array}{l}\text { 中の } \\
\text { 㚎縕 } \\
\text { 腔胞 } \\
\text { 粘浸 } \\
\text { 膜潤 }\end{array}$ & $\begin{array}{l}\text { 中の } \\
\text { 哲毛 } \\
\text { 腔緗 } \\
\text { 粘血 } \\
\text { 腅管 }\end{array}$ & $\begin{array}{l}\text { 骨 } \\
\text { 第 } \\
\text { 維 } \\
\text { 胞 }\end{array}$ & $\begin{array}{l}\text { 破 } \\
\text { 骨. } \\
\text { 緗 } \\
\text { 胞 }\end{array}$ & 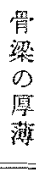 \\
\hline 1 & I & 40 & \multirow{11}{*}{ 月 } & $\mathrm{HH}$ & $\mathrm{Ht}$ & $\mathrm{HH}$ & $\mathrm{HH}$ & $\mathrm{HH}$ \\
\hline 2 & 11 & 40 & & + & HH & $t$ & + & + \\
\hline 3 & 12 & 40 & & $H$ & $\mathrm{Ht}$ & $H$ & + & $H$ \\
\hline 4 & 15 & 40 & & $H$ & Ht & $\mathrm{Ht}$ & $H$ & $H$ \\
\hline 5 & 3 & 38 & & + & + & $H$ & + & + \\
\hline 6 & 14 & 38 & & $H$ & $H$ & Ht & $H$ & $H$ \\
\hline 7 & 16 & 38 & & $H$ & $H$ & + & + & $H$ \\
\hline 8 & 5 & 37 & & + & $\mathrm{HH}$ & $t$ & + & $H$ \\
\hline 9 & 7 & 37 & & $H$ & $\mathrm{HH}$ & $H$ & + & $H$ \\
\hline 10 & 8 & 37 & & + & + & + & + & + \\
\hline 11 & 13 & 37 & & $H$ & $\mathrm{HH}$ & $H$ & $H$ & $H$ \\
\hline 12 & 2 & 36 & \multirow{4}{*}{$\begin{array}{l}9 \\
\text { 多 } \\
\text { 月 }\end{array}$} & H & $\mathrm{HH}$ & $H$ & $\mathrm{HH}$ & $\mathrm{HH}$ \\
\hline 13 & 4 & 36 & & $t$ & $\mathrm{HH}$ & $t$ & + & $H$ \\
\hline 14 & 6 & 36 & & $t$ & + & $t$ & + & $H$ \\
\hline 15 & 9 & 36 & & Ht & HH & $H$ & $H$ & $\mathrm{HH}$ \\
\hline 16 & 10 & 32 & \multirow{4}{*}{$\begin{array}{l}8 \\
\text { 力 } \\
\text { 月 }\end{array}$} & $H$ & $H$ & $H$ & $H$ & $H$ \\
\hline 17 & 21 & 32 & & + & $\mathrm{HH}$ & $H$ & $H$ & $H$ \\
\hline 18 & 22 & 32 & & $t$ & $\mathrm{HH}$ & $H$ & + & $H$ \\
\hline 19 & 25 & 32 & & $t$ & $H$ & $H$ & + & + \\
\hline 20 & 17 & 28 & \multirow{4}{*}{$\begin{array}{l}7 \\
\text { 力 } \\
\text { 月 }\end{array}$} & $H$ & $H$ & $H$ & $H$ & $\mathrm{Ht}$ \\
\hline 21 & 18 & 28 & & $H$ & $H$ & $t$ & $t$ & $H$ \\
\hline 22 & 19 & 28 & & + & $H$ & $H$ & $H$ & $\mathrm{HH}$ \\
\hline 23 & 20 & 25 & & + & + & $H$ & $t$ & + \\
\hline 24 & 23 & 24 & 6 & + & $H$ & H & $H$ & $H$ \\
\hline 25 & 24 & 24 & $\begin{array}{l}\text { 少 } \\
\text { 月 }\end{array}$ & $t$ & $H$ & $H$ & + & $\mathrm{Ht}$ \\
\hline
\end{tabular}

を「十」，その中間程度の例を「サ」とした。

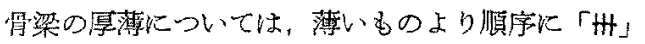
「H」,「十」とした.

その結果は表 4に示す如くである。

i) 細胞浸潤について

藷者の镜察例では，細胞漫閏の程度を個体的飞判別L 得たものは9カ月以降の胎児の例であつて，成熟胎児で

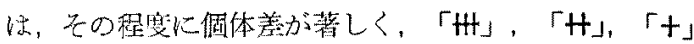
の三つの段階に分類したが，幼若週命の例で你，個体垱 が著明でない。
ii) 毛祖㐰管火ついて

㘥察例では全般的にみて，毛細血管の增殖は全例にお。 いて著るしく，血管の允血程度も著明であるが，一般 に，幼若な例では，粘膜の表临部に存在し，胎令が進む につれて，深部に侵入している像が鸹められた。

iii）管苏細胞以ついて

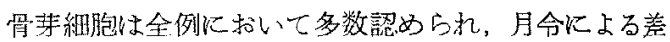
罢も著るしくなく，その出現の程度の個体的差異は著明 でない.

即ち全般的に骨增殖が著明であることを示している。

iv) 属骨綝胞について

破骨細胞は一般に骨苸細胞に比較して少なく，個体差 も藷るしく，容易に諰め得る例と譆め難い例とがある。

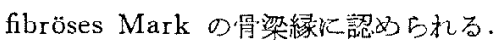

v) 骨梁の厚薄について

骨梁の愿薄は同一例でも見る場所によりて異なり，特

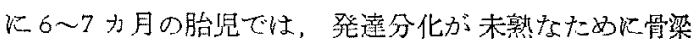
が薄く，個体差も著明でない。

\section{小括}

胎生未期の中耳腔を組織学啲に観寗すると，中耳腔の

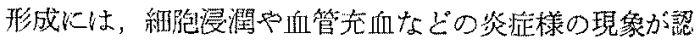
められるが，この現象は特に成熟胎見に著明に認められ た.この現象仗所謂 latente Säuglingsotitis と呼ばれ たものであるが，既にこの用題については，当教害の楖

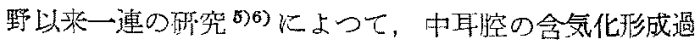

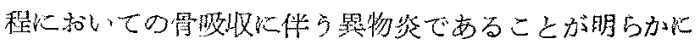
された。

細織学的に双て，中耳腔内の組胞浸㵎の著明な例で

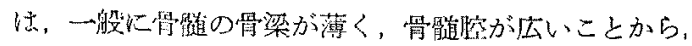
含桑化の良否によつて骨の構成状態儿差罢つ存在するこ とが的らかとなつた。この意味から傾融の含気化状態 に個体的な体澌的差異の存在することも明らかとなつた が，これと他の部位の骨の状態と比䍊することによっ 


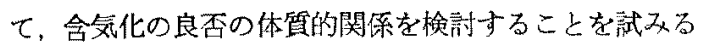
必要が生じて来た。

この目的のために，箸者は9カ月以降の胎巟につい て，中耳腔糊莫の紐胞浸潤と側頭骨の骨䯣腔の広さとの 関係を検索した。

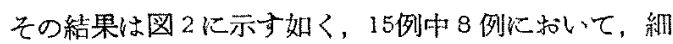
胞浸潤之側頭骨の骷腔の広さとの問に比例関係があるこ 々を認められ，細胞瀑潤が軽度で側頭骨の㨁道腔が広い、例 は，15例中僅か1例でありた。 また，細胞浸潤が著明で 鮪腔が小さい例は1例も認められなかつた。

図 2 中耳拼膜の細胞漫潤と側頭骨の 骨髅腔の広さこの関係

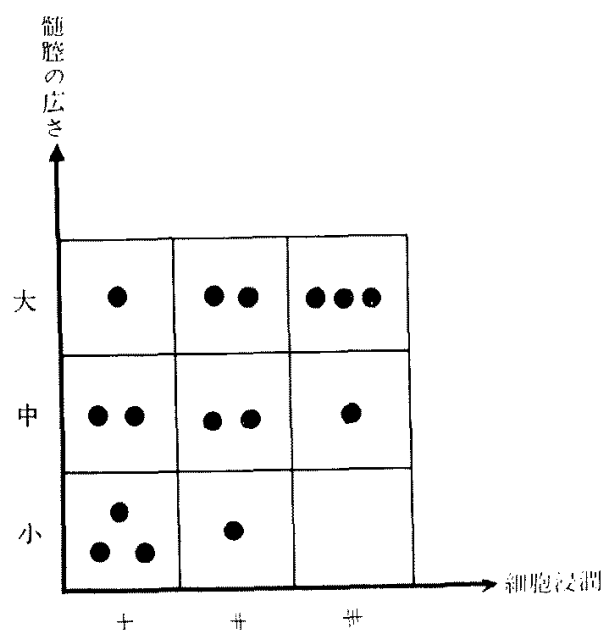

今回の著者の研究成績を検討すると，組織学的にみて も，又計測成績からみて子，含気腔形成の良好な例は全 身骨の骨粗腔が必ずしも広い，といら証哟はできなから たが，含気腔形成の不良の例には，骨䯤膑が広いという ことはあり得ないといい得る結果が得られた。従つて， 中耳腔発育（合気化）の個体差は全身の骨絽織之体質的 な類似性を持つているものと見做すことができる。

\section{IV 総括及び考按}

柳野は中耳腔の発育初期の研究から，含気悾の形成状 態には，Praenatal と Postnatal との間に明らかな一線 が劃さるべきるのでないといい，Wendt ${ }^{13)}$ 及び Wreden ${ }^{14)}$ は含気腔は生後の呼吸によつて成立寸るのでな いと述へててる。

小林 ${ }^{1016)}$ はV線学的に中耳 Pneumatisation の生後 の発育汇関する研究を行つて, 乳児期 (生後一年以内) の中耳蜂笨は基本的空腔の形成を主とするもので，䗋集
の形成忧レ線的に汸明らかに認められないが，同一個体

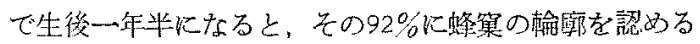
に至るといつている。これはレ線学的には，生後一年を 過ぎると，中耳䗋柋の形成が盛ん行われていることを 示している.

新生見及び胎生未期の胎児の中耳腔にみられる所謂 latente Säuglingsotitis (Wittmaack) と呼ばれる焱

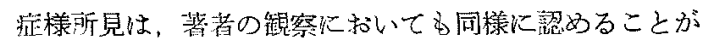
できな、この現象については，柳野その他一道の教室の

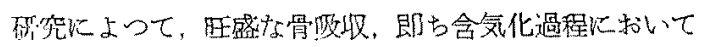
の異物反応であることが知られている，

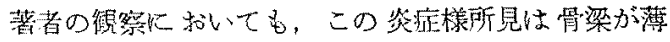
く，中耳腔の広い例に特に蓄明に認められたことから， 含気化の旺盛なことを表らわしている現象と思われた。

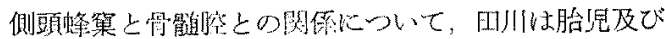
成人の側頭骨，顽媔骨及び大煺霄炕ついて組織学的にそ

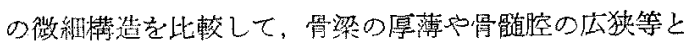
会気化状熊上恃相似た所見が認められるとし，含気化の 良好な側碩骨を持つ個体の頭頂骨及び大腿骨はいずれる 骨梁が薄く，骨骾腔が広い，反対に，含気化の悪い側頭 骨の個体では，頡頂骨，大限筲ともに骨梁が厚く，骨䯣 腔の発達が悪いといっているが，この研究は成人につい て，側頭骨の含気化現象の年令的推移を镜察すること卷 目的としたものであらた，

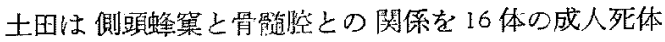
で形態学的に研究し，側頭䗋案の発達の良好なるのは胸 骨, 胸椎及び上腕骨の骨髄腔形成も良好で, 䗋策発澾の 不良の毛の红骨䯣腔形成子不良で方るといらている。し

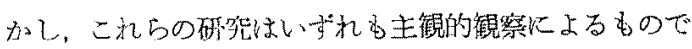
あつたから，著者はこ机を出来るだけ計測的に観察する ことを企図した。

著者は骨含気腔小，その構成骨の骨噵腔の部分が吸収

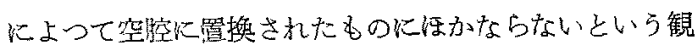
地から，中耳腔と全身骨格の骨䯙腔との関係を比較し， 出来るだけ，他賞的に，数值的に钼察することる試みた るのである。

著者の矿究の結果では，含気化良好の例で傾頭骨の骨 䯙腔が広いという例は 15 例中 8 例比認められ，含気化 不良の例で側頭骨の噵空広いとい5例は 15 例中僅か 1 例に認めら机た。しかし，含気化が良好で，側頭骨の骨 䯠腔が小さいといら例は1 例を認められなかつたといら ことは，含気腔形成とその檴成骨の骨䭒腔との間に，密 接な関連性があるとみなすことができる。 


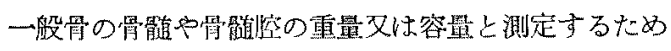
に，幾多の学者によつて種々の力法が企てられた。

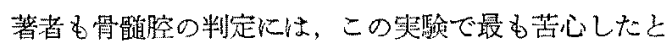
ころであつたが，文献においては，Mechanik 17) 体の骨路重量湘定し，Nye 22)，Fairman and Whipple 18), Fairman and Corner 19) 等(t. Clostridium hystolyticum の磨敗性を利用して骨骮院の容量を测定

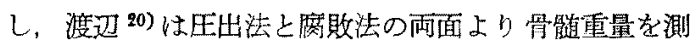

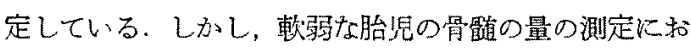
いてこれらの方法を用いることは不可能であるので，著 者は研究万法に执いて速べた如き方法を用いることとし たのである.

文献に示された方法によつても，骨髓量には個体差が 著るしく，また，人胎监については，骨䯣量の測定報告 がないので，著者の方法による成績は他のこ机と比較す る文献を見ることができなかつた。

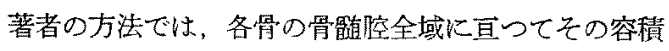
を測定することは，校術的に困難なことであるから，前 記の上らに部分的な測定方法をとつて, 各骨の骨髄腔の 「大」，「小」を判定した。

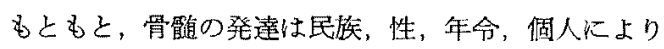
著しい差異があるといわれているが，このこと性側頭蜂 穼に個人差が著明なことと一致している。しかし，両者 とも個人差が著明であるといいても，骨髄は造血器官で あることから，一般の骨では個人差の範用に一定の制約 の存在することは諒解するに難かしくない、これに反し

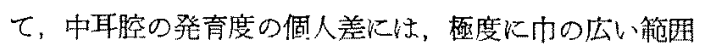
が存在している.

これらを既に著しい発育段階にある胎性未期の胎巟で 检索した著者の研究において，側頭骨の骨䯣腔の大きさ

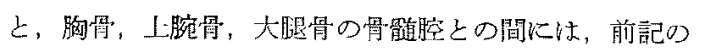

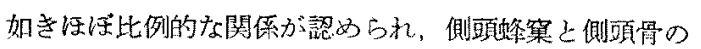
骨䯠膑の大きさ之の間には，15例中8例压おいて比例関

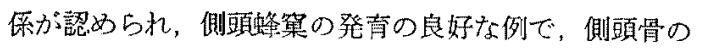
骨髓㱐が小さな例は，1例も認められなかつたといらこ とは, 側頭蜂穼の発達の良否が胸骨々の他の骨髄膑形成 の良否と体質的な関係があるこを澺味しているもの上 見做すことができる。

しかし，両者の関俰で必ずしも密接に亚行した結果が 得られていないことは，既に㣪藤教授の研究 21)で証明 されている如く，含気腔の発育抑制状龍には，側頭骨に 执いては，一側的に，をた，独立的に発現し得るといら ことからみて，側頭骨の含気化は全身の骨の状熊と常に
一致するものとは限らないとする著明の結果と一致して Wる.

\section{$\mathbf{V}$ 結 言}

中耳及び乳様㛔窠の発育，即ち含気化は側䌿骨の骨䯣 腔の存在と密接な関係があり，個体差が著るしく，従つ て中耳及び乳様捀集の含気化の良否之，衄幹骨のそれと の開に，いかなる関望性があるものか，又，軀幹骨の骨

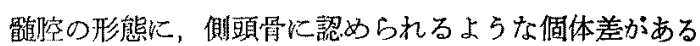
ものかどらか，この問題の研究のために，著者は6力月 以降の人胎児 25 例を用いて，中䎳び乳様捀集の発育

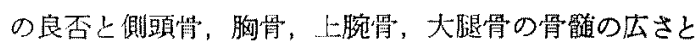
を比皎した。

及，所謂 latente Säuglingsotitis こ西びれれた中耳腔 内の潜在性炎症について観察すると同時に，年の時期に 相当する軀幹骨の骨骨道膑の状熊む観察した。

その結果は次の加くである。

1）側頭骨の骨䯣腔と胸骨のとれとの閏には，19例中 13例に比例関俰が認めら机た。

2）側頍骨の骨䯠腔と上腕骨のそれとの間には，19例 中16例に比例関係が認められた。

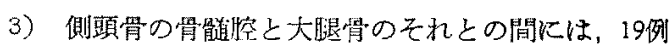
中10例に比例関俰が認められた。

4) 側頭䗋壶の発育と側頭骨の骨艏腔の広さとの間に

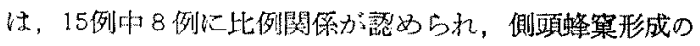
良好な例で，側頭骨の骨䯣腔が小さな例は，1例名証め られなかつた

以上のことより，中耳腔発育（含気化）の個体差は， 全身の骨組織上体質的な類似性を持つているものと見做 すことができた。

\section{VI 考文献}

1) Wittmaack: Uber die normale und die pathologische Pneumatisation des Schlafenbeins. Gustav Fischer, Jena, 1918. 2) 後藤敏郎, 永田静

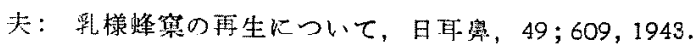
3) 後漛解郎: Säuglingsotitis Kついて, 耳喉, 25; 113，1953.4）柳野校次郎: 中耳浲集発育初期に見 5れる炎症様所見比関寸る研究，日耳鼠，56；942，

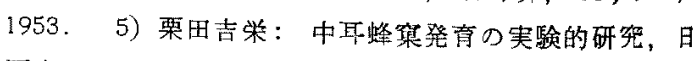

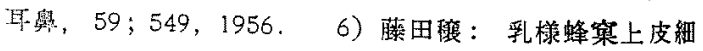

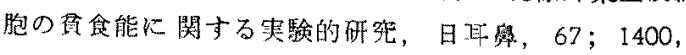
1964７７）田川大吉郎：含気腔を持つた骨と一般骨と の比較，日开愁，63；1062，1960. 8) 土田武正：㑡

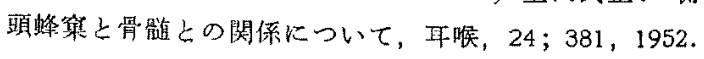




\section{溝上論文付図}

写真 1

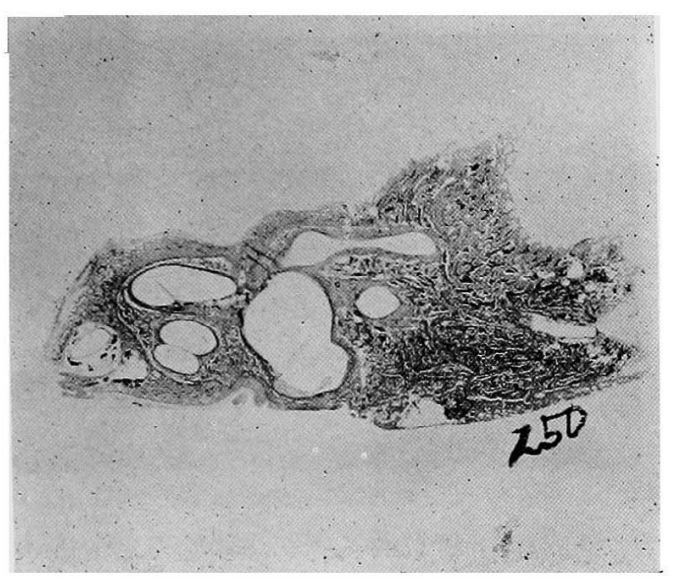

写真 3

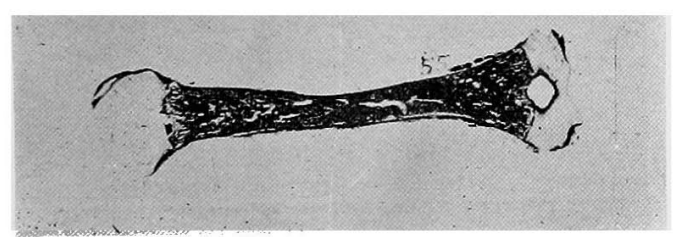

写真 5

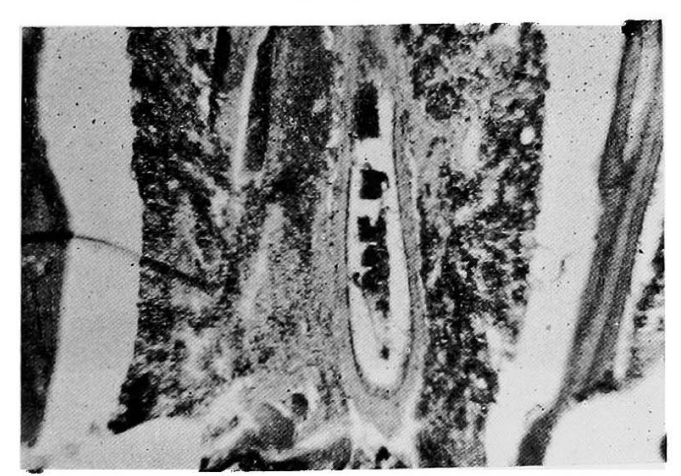

写 真 2

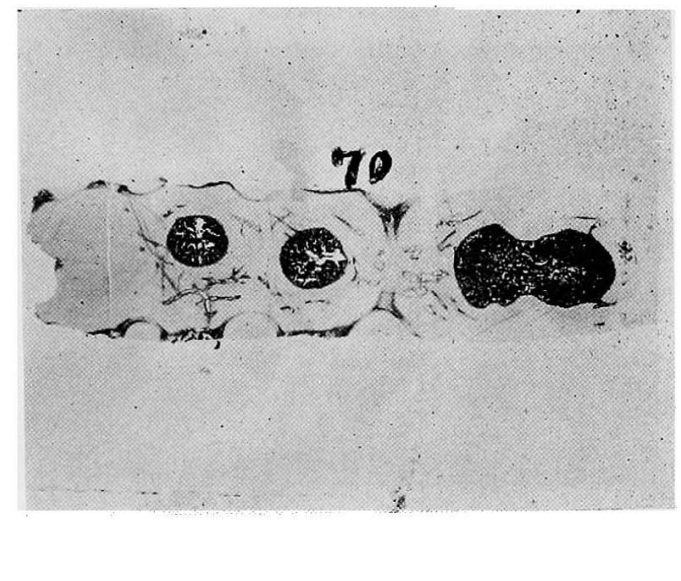

写真 4

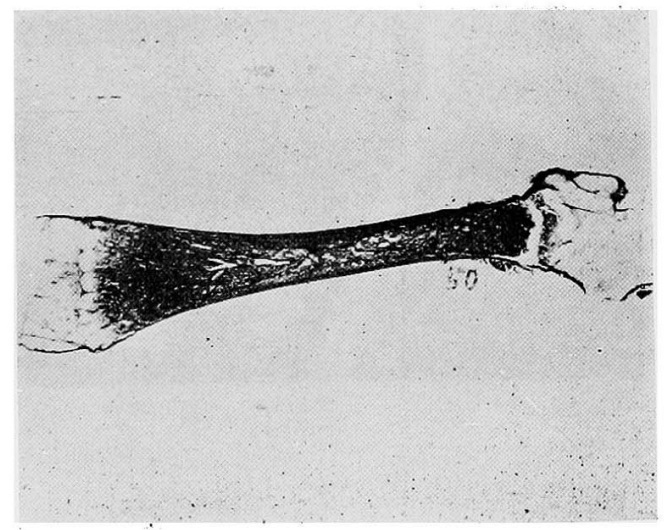

写真 6

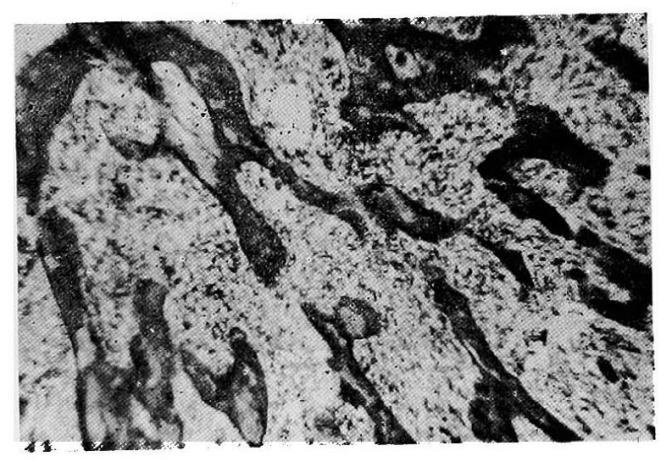




\section{溝上論交付図 ॥}

写 真 7

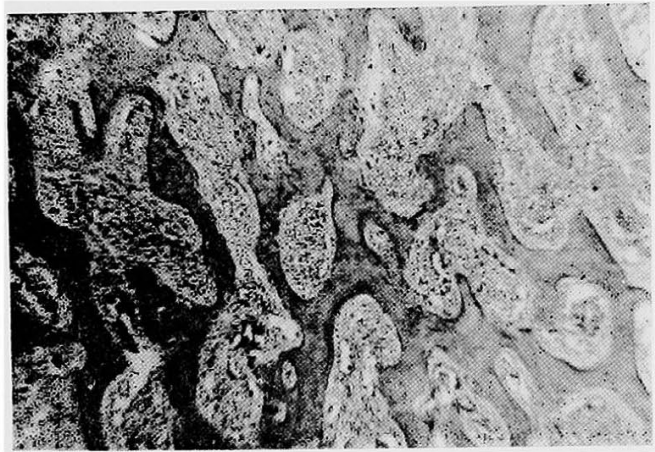

写真 9

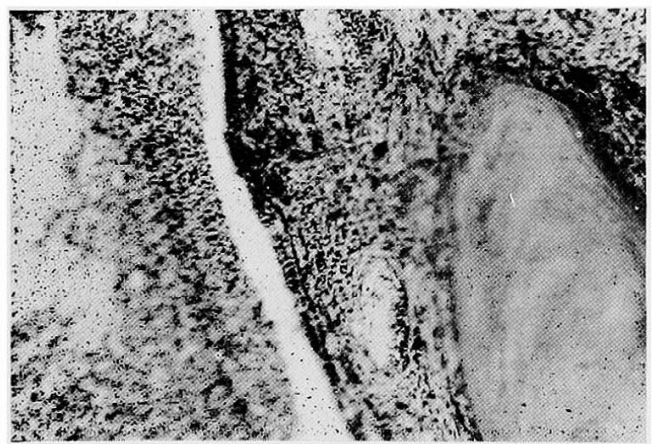

写真 11

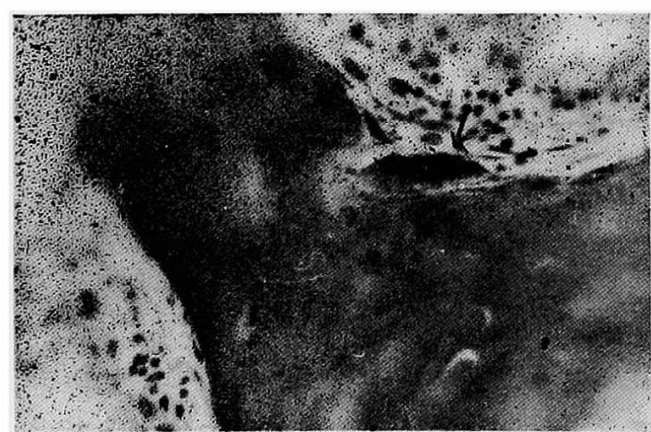

写 真 8

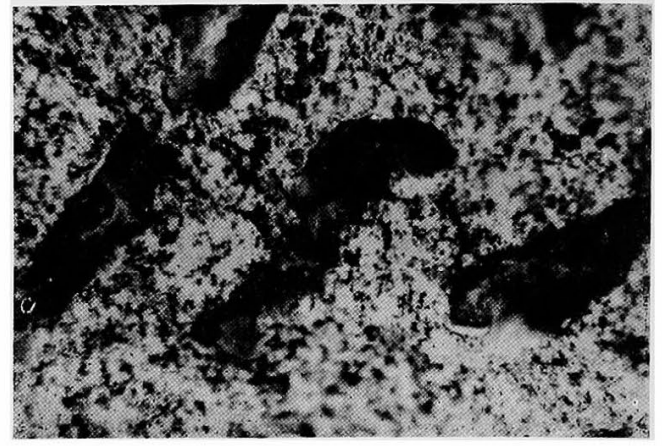

写真 10

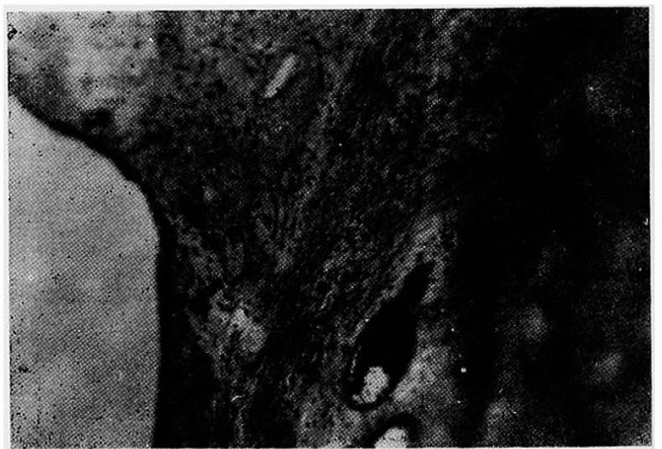

写真 12

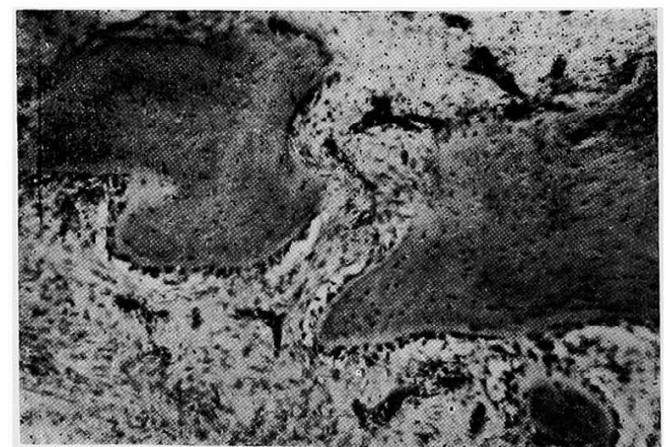




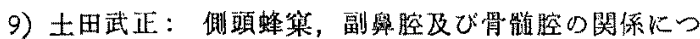
いて，耳鼻臨床，45；419，1952.10）光增昭：虺层 学的に Pn-hemmung と短身について，日聚，58;

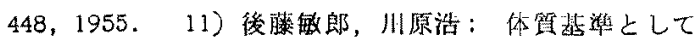
の乳様蜂案の形態, 日耳.舆，55；410，1952. 12）不 破成和：中耳 Pn. の発觜之全身発热との関俰，日耳:

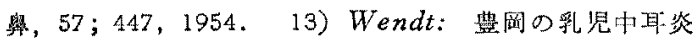

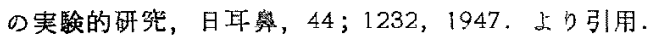

14) Wredn: 13) に同じ. 15) 小林泰：吅非 Pn-

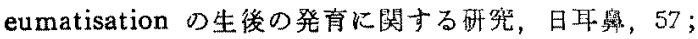
196，1954. 16）後藤敏郎，小林泰：乳幼児に拈ける

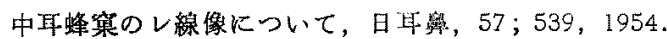

17) Mechanik: Über das Gewicht des Knochenmarkes des Menschen. Zeitschr. F. Anat. u. Entwickl., $79: 58,1926.18)$ Fairman and Corner: The bone-marrow volum of the albino rat. Anat Rec., 60:1, 1935. 19) Fairman and Whipple:

Bone-marrow volum in adlut dogs. Am. J. Physiol., 104；352，1933. 20）渡辺静夫：骨䯣の重量につい $\tau$, 日血九地誌，5；131，1954，21）後藤敏郎：

Pneumatisation $の$ 成立々无の臨床，日耳湛，55；68，
1952. 22) Nye: Bone-marrow volum in rabitts. Proc. Soc. exp. Biol,, a. Med. 29 ; 34, 1931.

\section{写真の説明}

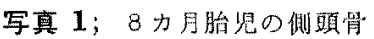

写真 2; 10力月胎昆の胸哲

写真 3; 9 力分胎忨の上腕骨

写真 4; 9 力月坚の大腿罜

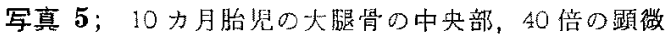
鋅写筫

写算 6; 写真 5 と同じ例の骨端部附近

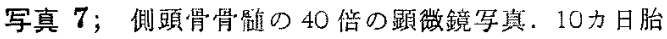
少

写真 8; 9 力月胎罗の胸骨骨鿷，100倍

写真 9; 10 力月胎児の中耳粘膜に叔ける，緗胞漁潤 の著膭な列

写真10；10 力月胎見の中互粘膡の細胞浸潤の著明で ない例

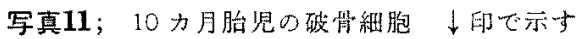

写真12；10 力月胎児の骨·䯣骨梁緣の骨芽細胞

（原稿到着二炤和 42.3 .27 日） 